\title{
Preface - The 'Gatekeeper' of Express Polymer Letters is 65
}

\author{
T. Czigány*
}

Department of Polymer Engineering, Faculty of Mechanical Engineering, Budapest University of Technology and Economics, Müegyetem rkp. 3., H-1111 Budapest, Hungary

Dear Readers,

The 2015 March issue of eXPRESS Polymer Letters is dedicated to our editor in chief, Prof. Dr. Dr. h.c. József Karger-Kocsis on the occasion of his $65^{\text {th }}$ birthday. This is the $99^{\text {th }}$ issue of this journal, and to its appearance credit should be given to professor Karger-Kocsis. His genius consistence, his strict standards in quality were guaranties of the continuous development of the journal. The gatekeeper supervises which papers may even enter the gates and from those which will be published in the end. The legendary devotion of professor Karger-Kocsis to everything belonging to his profession raised $\boldsymbol{e X P R E S S}$ Polymer Letters to the level of best journals and made it reputable all over the world.

Professor Karger-Kocsis was born in March 1950 in Budapest, received his diploma from the Faculty of Chemical Engineering of the Budapest Technical University. He received his Dr. techn. in 1977,

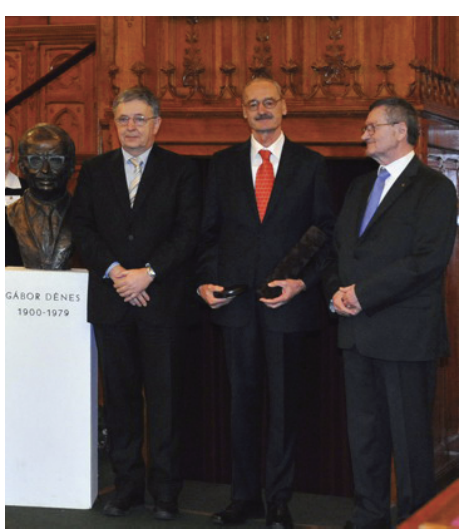

Academy of Science. His main research interest covers the improvement of the properties of polymers and their composites, their testing and applications; development of material testing methods; investigation of matrix/reinforcement interfacial interactions and utilization of plastics and rubber wastes. The quality of his research is shown by the fact that he is the author of more than 500 publications (books, book chapters, journal articles and conference proceedings). His cumulative impact factor is at about 500, and his number of independent citations is close to 10000 . He has more than 30 patents, several of them being used by the industry. Professor Karger-Kocsis is an internationally renowned scientist, who, in addition to his Hungarian mother tongue, is fluent in six further languages. He established his own school, having dozens of PhD students who inherited his specific professional world-view and propagated it all over the world. Recognizing his work, the Novofer Foundation honbecame candidate in science in 1983 and the acquired the DSc degree of the Hungarian Academy of Science in 1991. He worked in the industry and in an industrial research institute. Then he was granted a Humboldt Research Fellowship and worked afterwards at the TU Hamburg-Harburg, at the Institute of Composite Materials of the TU Kaiserslautern in Germany, and at the Tshwane University of Technology in South Africa. At present, he is a professor of the Department of Polymer Engineering of the Faculty of Mechanical Engineering at the Budapest University of Technology and Economics and he is also a member of the Composite Technology Research Group of the Hungarian

${ }^{*}$ Corresponding author, e-mail: czigany@eik.bme.hu (C) BME-PT ored him with the Dennis Gábor prize - 2014 which was handed over in the Parliament by the president of the Hungarian Academy of Sciences and the curator of the Novofer Foundation (see the photo).

The authors of this issue are professor Karger-Kocsis' friends, present and former colleagues, and students, who selected topics representing the main research fields belonging to professor Karger-Kocsis.

With this issue, in the name of the authors and the scientific community, I would like to express my best wishes to professor Karger-Kocsis on his birthday.

Prof. Dr. Tibor Czigány editor (one of the disciples) 